\title{
V. Repatriation and Development Assistance
}

\author{
Robert F. Gorman and Gaim Kibreab
}

The authors argue that refugees should be seen as agents of a process of development to begin during temporary protection and extend well into the process of return and reintegration. The process of development advocated is intended to engage local resources and energies in the refugee, host and stayee communities, in a "bottom-up" fashion. It involves a unified international role in allocating resources, enlivening and promoting development at the local level, and ensuring accountability. The mechanisms proposed require "judicious, not lavish" external resources, and establish a continuum between emergency relief operations and long-term development assistance. This is a substantially abbreviated version of the authors' original work. Please refer to the notice at the end of this section if you are interested in obtaining a full copy of the paper, which is expected to be published in mid-1996.

There is an important connection between flight and return and development. Flight has developmental implications both for the country of origin and the country of receipt, in that refugees and returnees can as easily be agents for development as burdens on development.

We wish also to underscore that development, wherever it exists, is principally the result of alocal population's energies and activities. Genuine development is self-reliant development. The point is that no development takes place unless it is the genuine by-product of the efforts, imaginations, and aspirations of a local population. The principles we propose for the establishment of a regime for Temporary Asylum and for Repatriation Aid and

\footnotetext{
Professor Robert F. Gorman, Department of Political Science, Southwest Texas State University.

Associate Professor Gaim Kibreab, Department of Economic History, Uppsala University.
}

Development, flow from these underlying realities. We have also concluded that such a new regime of refugee protection will work best when the international community actively engages in addressing the root causes of refugee flight, and in bringing diplomatic pressure to bear on local governments and opposition groups to resolve their disputes. The system that we propose in the following analysis, then, is best coupled with the political, diplomatic, and perhaps even military engagement of the international community in the interests of restoring peace and security.

Developmental implications of emergency assistance should be taken into account at the outset, and the local population and the refugees or returnees should, in principle, be incorporated into the planning and implementation of projects. There must be a linkage of infrastructural projects (bricks and mortar type projects) with self-reliance and income generation components (the human improvement aspect of development). Dispensers of refugee aid should be conscious of its developmental effects, and development aid should account for the impact that refugees and returnees have on the economic and social infrastructure and on the population of refugee and returnee-affected regions.

The system of Refugee Aid and Development that we propose in countries of asylum incorporates selfconsciously many of the widely acknowledged principles mentioned above, while calling for an international supervisory authority to take institutional control at the international level for allocation of resources, and at the same time enlivening and promoting a system of development planning at the local level. The system of temporary asylum adopted here also embraces the principle that countries hosting large numbers of refugees who have fled from neighbouring states should be provided assistance to compensate for both the humanitarian and developmental costs of asylum. This is, we believe, an important element of preserving protection.

But what are the appropriate modalities of assistance? The bulk of emergency, care and maintenance assistance should continue to be provided by the international community. Additionally, where refugee populations place burdens on the local infrastructures (education, health, water supply, security systems, food storage, roads, environment, social services, range and land management, wood and energy supply, etc.) the host government and population should be provided assistance to compensate for these burdens and to strengthen the infrastructural capacity of refugeereceiving areas. The effects of large refugee populations on local agriculture and employment should also be taken into account. But this compensation should be based on documented needs, and it should be adequate to meeting just those tasks found most wanting. Money alone is not the key to development. The key is in stimulating, rewarding, and supporting initiative.

Large refugee flows are often conceptualized as development depressing events, insofar as they impose development burdens. This conception of refugee events ignores the fact that refugee and local populations, though often facing great exigency and stress, are quite resourceful. We believe that any new regime for temporary asylum and facilitation of repatriation must take this fact into account. Thus, from the very outset of a refugee event, we recommend that the international community shift the emphasis away from the international to the local. We propose that, prior to any funds being allocated for local 
infrastructural assistance, two local bodies be created: a Refugee Development Council (RDC) and a Local Development Council (LDC). The RDC should be composed of representatives of the newly arrived refugee population, including, where appropriate, community elders. Where appropriate, the RDC should be elected, but this will vary with the circumstances of the case. Similarly the LDCs should represent the economic, tribal and geographical interests of the host country population. Though stressing traditional elder roles, RDCs and LDCs should be viewed as a means of identifying and unleashing skills that exist among the local and refugee populations, including doctors and traditional healers, engineers and teachers, economists and entrepreneurs. They should also be so composed as to reflect the special needs and interests of women. We recognize, in this connec- tion, that some of the traditional leadership structures are undoubtedly unrepresentative and oppressive, but change, including gender-related change, ultimately must come from within. Outside intervention can only be facilitative.

An effective system for returnee aid and development must be linked with ongoing strategies for repatriation in the country of temporary asylum. It must take into account the fast-changing reality of global politics, the indivisibility of the processes of repatriation, reconstruction, development and peacemaking, the capability of displaced people to reconstruct their own communities, given a chance, and the right of people to remain, or if displaced, to return to their country or place of origin in conditions of safety and dignity.

Under the principles inhering in the regime we propose, conditions in the country of temporary asylum will focus on the development needs of the host country and the ultimate reintegration of the refugee population into an improved development context in the country of origin. Far from increasing the arbitrary nature of voluntary repatriation as it has often been experienced in the past decade, such a system should at once reduce pressures for repatriation from the government of temporary asylum and increase incentives for return. But all this hinges on the willingness of governments to accept a new system of principles and procedures that are solution oriented, that aggressively promote peaceful resolution of disputes in countries of origin, that promote the expansion of local development capacity and that are backed by adequate financial support.

\section{Asylum-A Moral Dilemma}

By W. Gunther Plaut

Toronto: York Lanes Press; ISBN 1-55014-239-9; 192 pages, indexed; $\$ 19.90$.

Every year the refugee landscape changes, but only in that more problems are added, fewer are solved, and all become constantly more urgent. Fuelled by the explosion of the world's population, the quest for asylum is one of the most pressing problems of our age. Refugee-receiving nations-located frequently, but by no means exclusively, in the Western world-have to respond to masses of humanity searching for new livable homes. Human compassion for these refugees can be found everywhere, but so can xenophobia and the desire to preserveone's nation, economic wellbeing, and cultural integrity. The clash between these impulses represents one of the great dilemmas of our time and is the subject of Plaut's study. In exploring it, he provides a far-ranging inquiry into the human condition.

The book presents political, ethnic, philosophical, religious, and sociological arguments, and deals with some of the most troublesome and heartbreaking conflicts in the news.

Contents: Tbe Issues; Questions Without Answers; Definitions; Religion, Natural Law, and Hospitality; A Look at History; Some EthicalQuestions; Through the Lens of Sociobiology; Community and Individual; Contended Rights: To Leave, Retum, Remain; The Practice; Refugees in Africa; Four Asian Lands; Glimpses of Europe and Central America; The North American Experience; The Sanctuary Movement; A Final Look; Appendix A: Egyptian and Hittite Treaties; Appendix B: Human Rights-Major Documents; Appendix C: Refugee Documents; Protocol Relating to the Status of Refugees of 31 January 1967; Bibliography; Index.

W. Gunther Plaut is a senior scholar at the Holy Blossom Temple in Toronto. Born in Germany, where he received his doctor of laws, he fled Hitler's Reich for the United States where he became a rabbi, serving in Chicago, St. Paul, and since 1961 in Toronto. Plaut is the author of 19 books, including Torab: A Modern Commentary (with B. Bamberger). His recommendations on the refugee determination process, submitted in 1985 at the invitation of the Canadian government, had an impact far beyond Canada's shores.

Asylum-A Moral Dilemma is simultaneously published in the United States by Praeger Publishers.

Available from York Lanes Press 